\title{
Factors driving the share and growth of Chinese entrepreneurship in Italy
}

\author{
Roberta Apa*, \\ University of Bergamo, \\ via dei Caniana 2, 24127 Bergamo, Italy \\ roberta.apa@unibg.it \\ *Corresponding author

\section{Ivan De Noni} \\ University of Brescia, \\ C.da Santa Chiara 50, 25122 Brescia, Italy \\ ivan.denoni@unibs.it
}

\section{Andrea Ganzaroli}

University of Milano,

Via Celoria, 2, 20133 Milano, Italy

Milano andrea.ganzaroli@unimi.it

\begin{abstract}
:
Chinese entrepreneurship may represent an important growth lever for a manufacturing country like Italy. Chinese are both, one of the fast growing ethnic communities in Europe and one of the most entrepreneurial. The development of ethnic enclave further contributes to support the increasing role of migrant entrepreneurship on local development. In the last decade, Chinese community is expanding at regional level and its entrepreneurial attitude is strongly increasing compared to natives in despite of economic crisis. However, since Chinese entrepreneurs are not homogeneously distributed, looking at spatial and industrial dependence is crucial to better understand the Chinese entrepreneurship growth strategies and to suggest policies supporting and exploiting local network externalities potentially influencing the regional development. In this perspective, this study focuses on the role of Chinese community size and its capacity to stimulate entrepreneurial specialisation rather than diversification across industries as well as the industrial specialisation of the local system in driving the share and growth rate of Chinese
\end{abstract}


micro-entrepreneurship.

Keywords: ethnic entrepreneurship, entrepreneurial diversification, local specialisation, Chinese community, growth strategy, Italy

\section{Biographical notes:}

Roberta Apa is Research Associate at the Department of Management, Economics and Quantitative Methods, University of Bergamo, Italy. She holds a doctorate in Management from University of Milan. Her research has been published in journals such as International Journal of Project Management, Journal of Small Business and Enterprise Development, Construction Management and Economics, Journal of International Entrepreneurship. She has also contributed to several book chapters. Her main research fields are innovation processes of start-ups and small and medium enterprises, business incubators, entrepreneurial ecosystem and academic entrepreneurship.

Ivan De Noni currently is researcher at Department of Economics and Management of University of Brescia. He was research fellow at University of Milan in Department of Economics, Management and Quantitative Methods for several years. He completed his Ph.D. in Corporate Finance and Management in 2010 at the same university. He currently teaches business strategy, marketing and corporate governance. His main research interests are in the fields of knowledge management, innovation and internalization of SMEs, firms' networks and regional systems. Further studies vary from ethnic entrepreneurship to destination marketing and social media research areas.

Andrea Ganzaroli is lecturer of Social Media and Digital Marketing at the University of Milan. He got his Ph.D. in management from the Rotterdam School of Management. His research ranges into different fields of study: knowledge management and open innovation; innovative M\&As; entrepreneurship; trust; and virtual and geographically clustered communities. He has authored a number of books and has published many articles in international journals such as Technology Analysis and Strategic Management and Scandinavian Journal of Management. 


\section{Introduction}

Today, when in Europe the ghost of new walls looms and talking about immigration sounds a very difficult task, a number of studies attempts to claim that immigration, if regulated and managed, might represent an important lever of cultural diversity and creativity (Ottaviano and Peri, 2005; Florida, 2005; Lee et al., 2004), regional growth and development both for receiving and sending countries (Dana, 2007, Levent et al., 2003; Masurel et al., 2002; Nijkamp, 2003; Saxenian, 2002), innovation (Ozgen et al., 2013), entrepreneurship (Lee et al., 2004), and internationalisation (Dana, 2001).

In this background, the role played by ethnic entrepreneurship literature is very critical because of social and political tensions due to the fragile balance between the structural limits of a sustainable reception of immigrants and the benefits of their effective integration into the economic and entrepreneurial local systems.

Focusing on the case of Chinese in Italy, this paper attempts to argue the extent to which Chinese entrepreneurship supports the development and diversification of Chinese distribution across industries and regional systems. It supports the overall thesis that ethnic entrepreneurship may raise the integration more than ghettoisation process of immigrants and at the same time, enhance the regional development and growth opportunities.

The rational leading to focusing on the case of Chinese in Italy relies on the time-contingent and place-specific characteristics of their localisation and development strategy, their capacity to exploit the combination of market opportunities as well as their individual and collective competencies and attitudes (Kloosterman and Rath, 2001).

In the case of Italy, there were two factors that have boosted up the original development of Chinese entrepreneurship: the peculiar industrial structure, which was and is characterised by the prevalence of small and familyowned firms spatially organised in the form of industrial districts and specialising in low-tech industries, and the economic crisis of the 90s. The combination of these two drivers provided Chinese with plenty of entrepreneurial opportunities. First, Chinese were more capable than other ethnic groups to identify and exploit such opportunities because of their well-known entrepreneurial attitude and their collective capacity of sharing resources and competencies (Wilson and Portes, 1980; Portes and Bach, 1985; Zhou, 2004; Zhou and Cho, 2010). Second, on the ground of their 
manufacturing competences embedded in their regions of origin such as Wenzhou, Chinese did not exploit any available entrepreneurial opportunities but specialise on textile (Dei Ottati, 2014). In the long run, this strategy has carried out Chinese to be one of the largest ethnic community in Italy and Chinese entrepreneurship to be traditionally concentrated in the textile and clothing Italian industry.

Nevertheless, more recent literature points out that Chinese are no longer only active in the upper part of the textile value chain, but are moving downward and gaining control over the relationship with the final market (Dei Ottati, 2014; Dunford, 2006; Lan and Zhu, 2014). In this perspective, the shift of Chinese entrepreneurship toward the last part of the value chain has implied the diversification of Chinese entrepreneurship in both related and unrelated activities to exploit existing and new market opportunities. In addition, due to the recent economic crisis, Chinese entrepreneurship have found additional market opportunities, which have probably contributed to accelerate the diversification of Chinese entrepreneurship and stimulate the rising of new developmental patterns. It is not a coincidence if data from 2009 to 2013 highlights a mismatch between local entrepreneurship decreasing by $0,02 \%$ and Chinese entrepreneurship growing by $30 \%$ (Chamber of Commerce, 2015).

Focusing on this background framework, the paper explores both the extent to which two traditional factors, such as community and specialisation, are still significant in explaining the share of Chinese entrepreneurship across Italian provinces; and the extent to which diversification rather than community and specialisation may positively affect the recent growth of Chinese entrepreneurship.

Our analysis produces two main results. First, it provides us with some important confirmations about the dynamic that has supported the development of Chinese entrepreneurship in Italy. On the one hand, we find a positive relationship between size of the community and share of entrepreneurship in the province. On the other hand, the Chinese entrepreneurial propensity to specialise in the local districts of fashion and apparel manufacturing is largely confirmed. Second, they provide us with some relevant insights on the emerging trends underlying the growth of Chinese entrepreneurship in Italy. Chinese entrepreneurs seem inclined to move from the community to neighbouring provinces and their growth appears to be strongly related to their increasing entrepreneurial diversification.

The structure of the paper is the following. The next section summarises the institutional and historical setting within which Chinese entrepreneurship has developed. This section provides us with the historical background 
useful to contextualise our research hypotheses. In section 3 , the research design and methodology is introduced. The dependent, explanatory and control variables are defined and justified. Descriptive statistics and the results of the analysis are further presented in the same section and discussed in section 4. The final section is devoted to conclusions and further research directions.

\section{The development of Chinese community and entrepreneurship in Italy}

Chinese are known for following a peculiar migration pattern, which is characterized by the formation of ethnic enclaves (Zhou and Cho, 2010; Ganzaroli et al., 2013), communities of people and firms co-localising in specific and geographically bounded suburban areas. This is evident in the multitude of Chinatowns existing in the world. Chinese immigration strategy has not been dissimilar in Italy.

Chinese arrived in Italy as peddlers in the 20s. They formed a small community in Milan in the neighbourhood of Paolo Sarpi, which, at that time, was a peripheral area of Milan and today is one of the largest Chinatown in Europe (Ganzaroli and De Noni, 2017). Most of them was well-educated students, diplomats, and tradesmen, who had lived elsewhere in Europe before coming to Italy. Their integration was fostered by operating small business, marrying Italian women, and rising children who attended Italian school. In the $60 \mathrm{~s}$ and $70 \mathrm{~s}$, the Chinese population rose to 8.000-9.000 people thanks to the re-conjunction of relatives and the arrival of new Chinese from other parts of Europe and Asia. They established in other cities such as Florence, Bologna and Rome and most of them used to work in leatherwork, catering, textile or apparel manufacturing. Later, in the $80 \mathrm{~s}$ and $90 \mathrm{~s}$, Italy was characterised by a rapid and spike-like growth of Chinese immigration, due to the rapid growth of the apparel manufacturing industry and the several legal amnesties for undocumented immigrants (Ceccagno, 2003). Nowadays, Italy is the European country hosting the largest number of Chinese (Chang, 2012).

Another important issue portraying the migration pattern of Chinese in Italy is that the majority came from the coastal province of Zhenjiang and especially from the countryside around the city of Wenzhou. This is particularly relevant since the high propensity of the inhabitants of this region to migrate is typically explained by their proximity to the main maritime trade routes to the West, their long history of maritime trades and their propensity to be entrepreneurs. In this light, they consider "getting rich 
in Europe" a sort of birth right (Chang, 2012). However, in the early 70s, due to favourable migration policies both in China and in Europe and the rising of massive inequalities within the region of Zhejiang, there has been a massive increment of Chinese moving to Southern Europe and especially to Italy.

Chinese were mainly attracted to Italy by some very specific market opportunities. On the demand side, Italy offered them plenty of entrepreneurial opportunities ready to be caught. Italy was and still is a manufacturing country specialising on traditional industries, characterised by the diffused presence of small and micro family-owned artisan firms typically organised in industrial districts. In the late $80 \mathrm{~s}$, there was a strong demand for low-cost, flexible and unskilled subcontractors to deal with a rapidly growing demand. However, Chinese did not size all entrepreneurial opportunities, but mainly specialise in textile and clothing. As suggested by Dei Ottati (2014), referring to the exemplar case of the textile district of Prato, initially Chinese immigration met no obstacles and Chinese immigrants were seen more as an opportunity than a threat. Chinese entrepreneurs filled a gap of subcontracting work required by local firms, and rented or bought up premises from local ex-artisans who had closed down during the previous crisis or were closing their business due to the lack of successors. Furthermore, they also allowed to achieve greater flexibility and effectiveness in the organisation of the supply chain and were determinant in enabling the transition from the programmed schedule model of production to the so-called pronto moda (fast fashion).

On the supply side, Wenzhounese people were better suited to size the entrepreneurial opportunities made available in Italy and especially in the textile and clothing industry. First, Wenzhou has been one of the faster growing municipalities in China after 1980. Its success has been so straightforward to be considered as national model (Liu, 1992). Second, the Wenzhou model shares many similarities with the development of Italian industrial districts (Dei Ottati, 2014). It is based on mass initiativeness (Liu, 1992). The spirit of mass initiativeness was manifested in the rapid growth of household firms, which rose from 1,844 to 150,000 from 1979 to 1988 . Similarly, in Prato, the growth in the demand for subcontracting was met by the continuous and rapid start-up of new family businesses and by enlarging the social division of labour between firms (Dei Ottati, 2014). Such a division of labour is extended and thickened on the basis of family-ship and friendship (Marsden and Caserta, 2010). The fact that economic relations take place mainly among family members and people from the same town ensures that economic relations interact systematically and inextricably with social relations, and since such social relations generally hold among 
members of the same group, they imply a reciprocal solidarity, easiness of information sharing, and lower transaction costs (Dei Ottati, 2014). Thus, their business practices were largely compatible with those common in industrial districts. Third, the Wenzhou community is a globally distributed community. Thus, local entrepreneurs, embedded in their specific hosting context, could leverage on their transnational and long-distance connections with other overseas communities and with the original one back in China to build up a globally distributed value chain and capitalise on context specific competitive advantages (Dei Ottati, 2014; Lan and Zhu, 2014).

In spite of these more historical and well-investigated elements, in the last decade Chinese have shown a propensity to differently exploit their business community-based model by enlarging outside the community and diversifying their business activities in related and unrelated industries. This change opens new perspective of analysis because it links ethnic entrepreneurship to new opportunities of integration and regional development.

\section{Theory building and hypotheses testing}

Even if there are several studies looking at the expansion of Chinese entrepreneurship in Italy, those are mainly based on case studies analysis and do not provide a systematic explanation of the factors driving the development of this form of entrepreneurship. Differently, this studies attempts to achieve this objective by focusing on three major drivers: community, local market opportunities and industrial diversification. First, Chinese migration is characterised by an enclave or community model of migration where migrants organise themselves into ethnic communities abroad and occupy specific suburban areas. This social and institutional setting leads to a type of entrepreneurship which is inclined to be strongly community-based. Second, the development of Chinese entrepreneurship in Italy was influenced by some market opportunities driving Chinese specialisation in the textile and clothing industry. Third, we are looking at Chinese business model evolution where the diversification of the Chinese entrepreneurship in different areas and in different industries is a relative new and less explored phenomenon.

Based on this conceptual framework, this study attempt to understand the extent to which Chinese community, local market opportunities and the moving from specialisation to diversification might impact respectively on the share and the growth of Chinese entrepreneurship.

The share of Chinese entrepreneurship 
The theory of ethnic enclave suggests that the migration strategy of some ethnic groups, such as Chinese, is characterised by the co-localisation of a community of firms and community of co-ethnics (Wilson and Portes, 1980; Portes and Bach, 1985; Zhou, 2004; Zhou and Cho, 2010). Colocation and spatial clustering are important to nurture the formation of a dense network of strong, crosscutting social relationships, which constitutes a valuable resource for the conduct of social affairs and provide the base of trust, cooperation and collective action in such communities (Kloosterman and Rath, 2001).

In the early stages, proximity to community allows supporting the startingup and the competitiveness of ethnic businesses by fostering the access to a co-ethnic market, ethnic resources including credit (Sanders and Nee, 1996) and cheap labour. In particular, the large availability of co-ethnics willing to work at lower costs, for longer hours, with more flexible arrangement compared to natives or other ethnic groups is the condition sine qua non for the rootedness of Chinese entrepreneurship. Thus, the following hypotheses should hold:

H1a: The larger the size of Chinese community the higher the share of Chinese entrepreneurship in a province.

Moreover, it is widely argued that the development of Chinese community in Italy has been driven by local market opportunities making the industrial district of textile, clothing, footwear and fashion a very fertile ground for their entrepreneurial and manufacturing abilities (Ceccagno, 2009; Dei Ottati, 2014; Lombardi et al. 2015).

As discussed in the previous section, in fact, the growth in the demand for subcontracting as well as the competitive market structure involving a large number of small and family-owned firms and the relative low entry barriers have contributed to make this industry very attractive. In addition, these market features fostered the setting up of Chinese businesses by requiring basic homeworking skills (such as how to use a sewing machine), low cost labour force (fostered by involving family members, friends and other coethnic immigrants), and modest investments (to purchase a few secondhand sewing machines) they can find within the community.

Because of this matching between local market needs and Chinese enclave offering, the textile and clothing specialisation of local provinces was one of the most important driver explaining the localisation and the extent of Chinese entrepreneurship in some specific districts. 
$H 1 b:$ The share of Chinese entrepreneurship is higher in province with a large degree of specialisation on textile and clothing industry.

Accordingly, the Chinese attention to as well as the rapid entrepreneurial involvement in the fashion market has undoubtedly favoured an initial specialisation of the Chinese entrepreneurship in this industry. This propensity is specifically fostered by two elements. First, they exploit the entrepreneurial and manufacturing competences they developed in their country of origin and in particular in Whenzhou city. Second, they leveraged on their long-distance connections to build up an ethnic-grounded transnational value chain and to gain control over market relations. Nowadays the large role the Chinese play in the textile and fashion Italian districts is so widely recognised that they are one of the main reference point for all textile European trades.

Following this perspective, in addition to historic concentration of Chinese within textile and clothing Italian districts, a large inclination of Chinese entrepreneurs to specialise in the relative industries is expected.

H1c: The Chinese entrepreneurial specialisation positively affects the share of Chinese entrepreneurship.

\section{The growth of the Chinese entrepreneurship}

In spite of factors driving the localisation strategies of Chinese entrepreneurship, some questions concern their growth and future development.

If the Chinese entrepreneurs are more likely to establish their business inside the area where the community lives, the example of Chinatown in Milan suggests they recently tend to establish in peripheral areas, far away from the metropolitan centre (Ganzaroli and De Noni, 2017). The typical localisation of the communities within the urban area, in fact, implies nowadays advantages and disadvantages. While, on the one hand, firms located in central areas could benefit from better business services, infrastructures and larger markets, on the other hand, they have to face with a high competitiveness and a high risk of market opportunities saturation and physical space saturation. This is amplified in the case of the textile and clothing Italian districts that are mature and currently offer lower market opportunities (Dunford, 2006). In this context, peripheral areas could provide fertile ground for new business because of lower price of acquiring 
and renting offices and other facilities required to start up a new businesses. In this perspective, moving into neighbour areas allows Chinese entrepreneurs to explore new market opportunities and remain in contact with the community, whose role remain relevant to appropriate the resources required for starting-up new sustainable businesses. Finally, we expect urban saturation encourages Chinese entrepreneurship to growth evermore outside the community due to the displacement of the new firms in the neighbouring areas.

H2a: The larger the size of Chinese community the lower the growth of Chinese entrepreneurship in a province.

The embedded features of Chinese entrepreneurship have led scholars to increasingly rely on concepts developed in the literature on agglomeration economies to explain the localisation patterns of Chinese entrepreneurship. According to Asheim et al. (2011), this literature is preoccupied with the question whether specialised locations are more conducive to innovation and growth, as compared with locations with more diversified industrial structures. In this perspective, the role of variety in sustaining growth is pointed out. The role of knowledge externalities and variety in sustaining the capacity of a community/territory to support local entrepreneurship has been recognised also by Audretsch et al. (2012).

Thus, even though the Chinese migration path and features have supported an increasing trend of businesses starting-up in the textile and clothing industry, nowadays we expect two main leverage of growth.

First, the maturity of the textile and clothing industry and in particular the saturation of the Italian textile and clothing districts might reduce the setting up of new firms. Thus, we hypothesise that the local textile and clothing specialisation, which has stimulated the rootedness of Chinese entrepreneurship in the past, is currently unable to support a further growth.

H2b: The growth rate of Chinese entrepreneurship is lower in province with a larger population of firms specialising on textile and clothing industry.

Second, recent literature points out that Chinese are no longer only performing the role of subcontractors, but are moving up and gaining control over the apparel value chain (Dei Ottati, 2014; Dunford, 2006; Lan and Zhu, 2014). This implies that Chinese entrepreneurship is diversifying into 
related and unrelated industries. For instance, Chinese are starting up many trading companies to manage the import/export of their production and the supply of row material, retail chains to sell their products to final consumers especially, but not only, to co-ethnics. Furthermore, there are Chinese companies specialising on the coordination and control of the supply chain and on fashion design. Gaining a position of control over the all stages of the value chain enable the Chinese community to further stimulate the development of entrepreneurship in related and complementary areas. Therefore, we expect a positive relationship between the diversification of entrepreneurship and its growth rate.

H2c: The diversification of Chinese entrepreneurial positively affects its growth rate.

\section{Methodology}

\subsection{Data and sample}

The aim of this study is to investigate the social and environmental drivers that affect the share and growth of Chinese entrepreneurship in Italian local systems as measured at NUTS-3 level. Specifically, we address the antecedents driving the share and growth of Chinese entrepreneurship during a five-years period from 2009 to 2013. Selecting a post crisis time window does not limit the assessment of such a period but conversely makes it even more interesting. In fact, if on the one hand, this crisis negatively impacted on the growth of local micro enterprises, on the other hand, it increased the market opportunities for Chinese entrepreneurs and maybe drove their diversification outside the community. In this perspective, we also consider the total growth (2009-2013) rather than year-by-year growth because it gives us a better understanding of those antecedents.

The final database is the result of the merge between two sources: the Italian Chamber of Commerce database on self-employment; and the ISTAT (Italian National Institute of Statistics) database on socio-economic and demographic data. The original database is composed of 110 provinces. However, since some provinces are relative new because of recent changes in the administrative borders, data are not available for all provinces. Therefore, the final sample is reduced to 104 provinces (Barletta-AndriaTrani, Carbonia-Iglesias, Olbia-Tempio, Ogliastra and Medio-Campidano are omitted). Furthermore, we also exclude the province of Prato to avoid biases due to the exceptional concentration of Chinese immigrant and 
businesses (Dei Ottati, 2014, Barbu et al.,2013; Santini et al.,2011). Statistically, the analysis of Cook's distance confirms Prato as outlier.

\subsection{Variables}

\section{Dependent variables}

The share of Chinese micro-entrepreneurship (SHARE_CHIN). Microentrepreneurship is measured by using self-employment data provided by Chamber of Commerce and classified by province and industry. The share of Chinese micro-entrepreneurship is operationalised for each province as the ratio between the number of Chinese entrepreneurs and the total number of entrepreneurs of the province. The index refers to 2009. We implement a log-transformation to normalise the density distribution (asymmetric distribution is shown by either the skewness test and the KolmogorovSmirnov test).

$S H A R E_{-} C H I N_{l s}=\log \left(\frac{p_{2009} l s}{P_{2009} l s}\right)$

where $l s$ is the local system, $p$ is the number of Chinese self-employers and $P$ is the overall number of self-employers embedded in the local system.

The growth rate of Chinese micro-entrepreneurship (GROWTH_CHIN). It measures the Chinese entrepreneurial dynamism and it is computed as the change in the share of Chinese micro-entrepreneurs over a five years period (2009-2013). This index is particularly important due to the conflicting trends of native and foreign entrepreneurship registered from 2007 because of the economic crisis. Thus, an increasing growth rate index may suggest the critical role of Chinese entrepreneurship in order to support the local resilience and development.

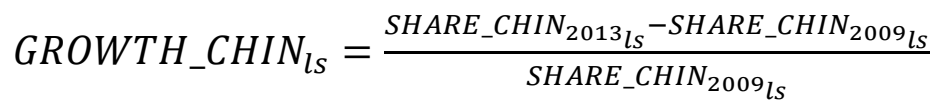

\section{Explanatory variables}

Chinese Community (CHIN_POP). The log-transformation of number of Chinese people registered in a province is applied as proxy of the size of the Chinese community. Several studies focusing on enclave economies (Portes, 1981, Aldrich and Waldinger, 1990; Portes and Shafer, 2007, Ndofor and Priem, 2011) argue the role of Chinese community to support entrepreneurship by providing a favourable captive market, financial 
resources and legal and illegal immigrant workers. Thus, the higher the number of Chinese in a territory, the larger is the community, the higher is the expected effect on entrepreneurial attitude.

Industrial diversification of Chinese micro-entrepreneurship (CHIN_VAR). We have already explained that micro-entrepreneurship is measured by using self-employment data classified by province and industry. Specifically the adopted industrial classification is the International Standard Industrial Classification of All Economic Activities (ISIC Rev.4) aggregation, which provides a top-level of 21 sections and a second level of 88 divisions (ISIC, 2008). The systemic variety of Chinese entrepreneurs between different industries is operationalised by using the Shannon entropy index at ISIC division level.

CHIN_VAR ${ }_{l s}=\sum_{i=1}^{N} p_{i_{l s}} \log _{2}\left(\frac{1}{p_{i_{l s}}}\right)$

where $l s$ is the local system, $p_{i}$ is the number of Chinese self-employers in each $i$ ISIC division.

Local specialisation in textile and clothing industry (LOC_SPEC). Since the Chinese migration has been driven by the availability of entrepreneurial opportunities in the Italian industrial districts and specifically in textile and clothing industry (Lombardi et al., 2011), local specialisation is expected to foster Chinese entrepreneurial share and growth. The higher the concentration of local firms in textile and clothing industry, the stronger the occurrence of Chinese businesses is expected. In this context, a location quotient (LQ) is operationalised to define the local specialisation in textile and clothing industry. The adoption of LQ as a geographical concentration measure is a classical technique used in economic geography to compare the presence of certain industries in a local economy with respect to a reference economy (Klosterman, 1990; Martin, 2012). It is measured as the ratio of the share of self-employers in textile and clothing industry at local and national level.

$L O C_{-} S P E C_{l s}=\frac{p_{\text {tex.ls }}}{P_{l s}} / \frac{p_{\text {tex.tot }}}{P_{\text {tot }}}$

where $l s$ and tot refer respectively to local and national level, $p$ is the number of self-employers in textile and clothing industry; $P$ is the total number of self-employers. A value of the index above 1 specifies that the share of self- 
employment in textile and clothing industry is higher at local than national level. Conversely, a value of less than 1 suggests a low concentration in the specific industry.

\section{Control variable}

Business density (BUS_DEN). This variable is measured as the ratio between the number of local self-employers and the number of inhabitants. Chinese entrepreneurs are not considered in order to reduces the risk of endogeneity. It is used as a proxy of local competition. The higher the degree of competition, the larger is the entry-exit effect, the more are the entrepreneurial opportunities for immigrant and Chinese businesses.

Urbanisation level (POP_DEN). It is measured as log-transformation of population density (population is divided by the square kilometres of the province). It is a proxy of urban externalities (Mameli et al., 2012). The higher population density the higher the level of urban services, such as universities, industry research laboratories, trade associations and other knowledge generating organisations (Frenken et al., 2007). Therefore, the higher the availability of those services the higher the level of entrepreneurship in the community. Immigrants may benefit from urbanisation economies both directly or indirectly. Directly, it may stimulate the development ethnic entrepreneurship in high tech industries, such as in the case of Silicon Valley. Indirectly, the availability of entrepreneurial and working opportunities in the high tech industries provide low skilled immigrants with the opportunities to start up their businesses in low tech industries.

Average business size (BUS_SIZE). This variable measures the average number of employees per firm by province. The average size of local firms is significant to understand the extent to which immigrants may enter the local market. In fact, the smaller the size of local firms the lower the level of entry costs. Thus, the easier is for immigrants to enter a local entrepreneurial opportunities.

Macro geographical area (AREA). In Italy, there is a strong disparity in terms of economic development and opportunities between North and South of Italy. In order to take into account of this effect, we introduce a set of dichotomic variables to distinguish provinces localised in the North-East, North-West, Centre of Italy or South and Islands. On the one hand, Chinese entrepreneurship in the North of Italy may be facilitated by the dynamicity of the economic environment, internationalisation and diffused industrialisation. Differently, in the South, it may be forced by the lack 
working opportunities and satisfactory job conditions (Light \& Gold, 2000; Baycan-Levent \& Nijkamp, 2009)

\subsection{Analysis and results}

According Chamber of Commerce, between 2009 and 2013 the number of Chinese entrepreneurs grew from 30,662 to 40,352 (+31.6\%). Similarly, their share grew form $0.9 \%$ in 2009 to $1.2 \%$ in 2013. In Figure 1, we show the quartile distribution of Chinese populations, entrepreneurial rate and growth rate in Italian provinces. The darkest colour highlights that Chinese population is concentrated in metropolitan areas and in the North-East part of Italy. The spatial distribution of self-employment largely overlaps with that of population. However, this concentration is higher in the provinces of the so called "Third Italy", where the presence of industrial districts is higher. Finally, Chinese entrepreneurship grows faster in the North-West area and in the provinces neighbouring those where Chinese entrepreneurs are already well established. This seems to confirm what Ganzaroli and De Noni (2017) observed in Lombardy. That is, Chinese entrepreneurship is becoming a regional phenomenon and, therefore, it should be approached as an ethnic regional system.
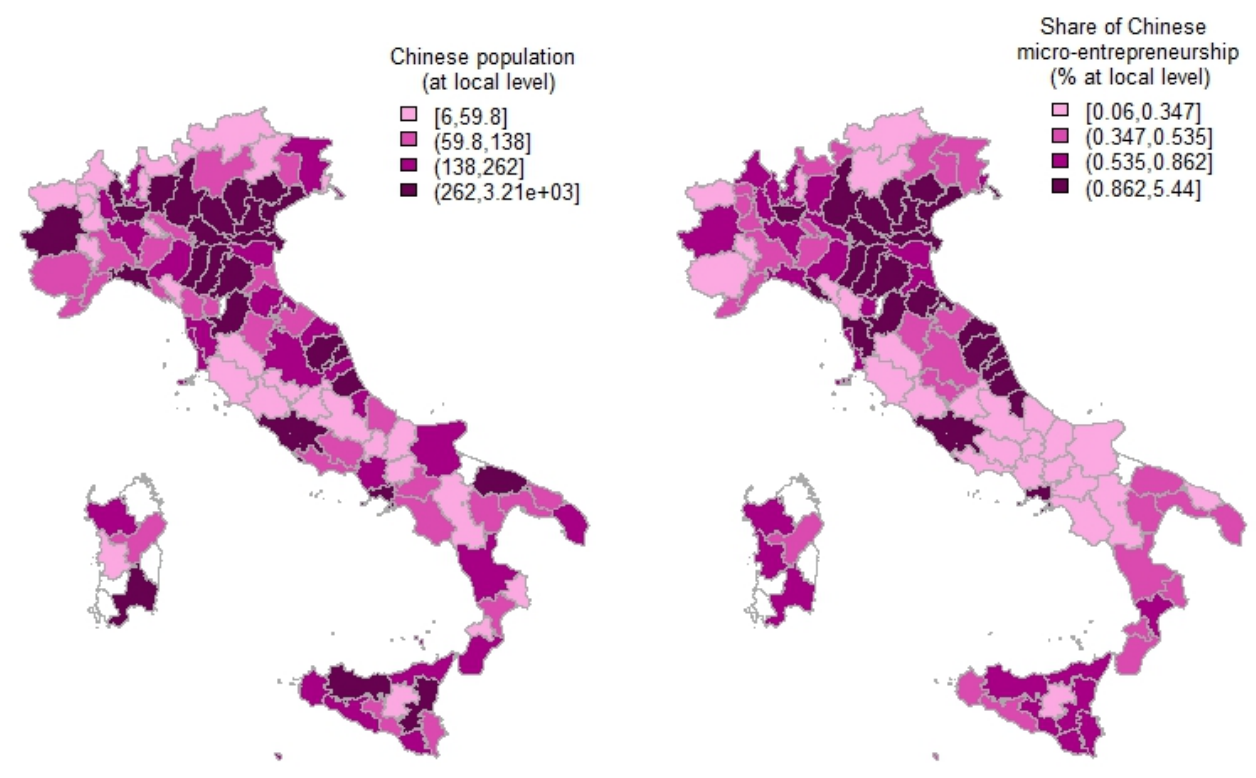


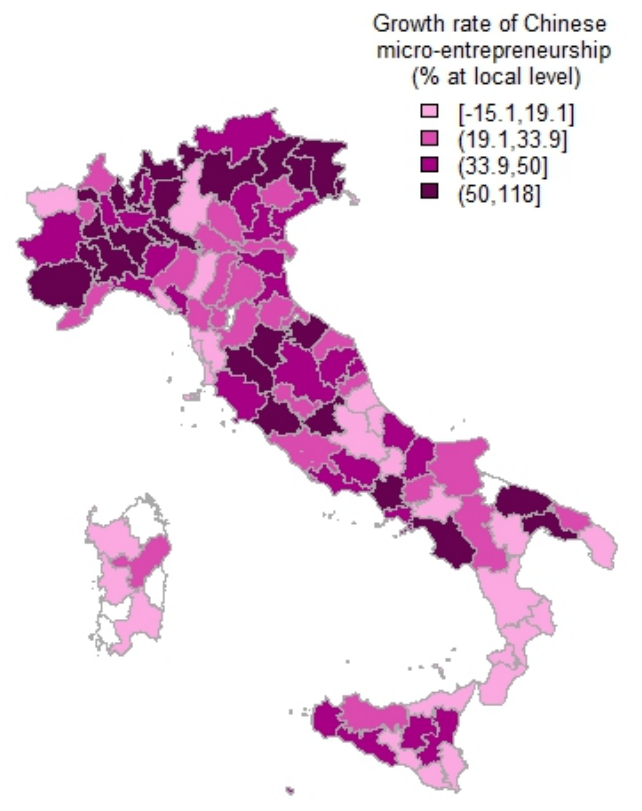

Figure 1. Quartile distribution of Chinese population, micro-entrepreneurship share and growth rate at local level

Looking at correlation matrix (Table 1), SHARE_CHIN is positively and strongly related to CHIN_POP $(r=.79)$, CHIN_VAR $(r=.43)$ and LOC_SPEC $(r=.61)$. Differently, GROWTH_CHIN is mainly related to CHIN_VAR $(r=.32)$ and negatively to CHIN_POP $(r=-.04)$. With respect to the control variables, POP_DEN is the main related to SHARE_CHIN $(r=.51)$ while BUS_SIZE is the main related with GROWTH_CHIN $(r=.24)$. No correlations between explanatory and control variables are over .70. However, multicollinearity test is further operationalised in regression models.

\begin{tabular}{|c|c|c|c|c|c|c|c|c|c|c|c|c|c|c|c|c|}
\hline Variable & $\operatorname{Min}$ & Mean & Std.dev & $\operatorname{Max}$ & 1 & 2 & 3 & 4 & 5 & 6 & 7 & 8 & 9 & 10 & 11 & 12 \\
\hline 1. SHARE_CHIN & 0,000 & 0,008 & 0,008 & 0,054 & 1 & & & & & & & & & & & \\
\hline $\begin{array}{l}2 . \\
\text { GROWTH_CHI } \\
\mathrm{N}\end{array}$ & $-0,151$ & 0,362 & 0,240 & 1,180 & $-0,31$ & 1 & & & & & & & & & & \\
\hline 3. CHIN_POP & 43,000 & 1462,000 & 2597,160 & 19939,000 & 0,79 & $-0,04$ & 1 & & & & & & & & & \\
\hline 4. CHIN_VAR & 0,000 & 1,443 & 0,805 & 2,988 & 0,43 & 0,32 & 0,59 & 1 & & & & & & & & \\
\hline 5. LOC_SPEC & 0,161 & 0,883 & 0,934 & 6,971 & 0,61 & $-0,03$ & 0,48 & 0,36 & 1 & & & & & & & \\
\hline 6. BUS_DEN & 0,037 & 0,062 & 0,015 & 0,135 & $-0,35$ & $-0,07$ & $-0,37$ & $-0,45$ & $-0,06$ & 1 & & & & & & \\
\hline 7. POP_DEN & 31,020 & 252,370 & 361,482 & 2586,260 & 0,51 & 0,01 & 0,59 & 0,44 & 0,22 & $-0,59$ & 1 & & & & & \\
\hline
\end{tabular}




\begin{tabular}{|c|c|c|c|c|c|c|c|c|c|c|c|c|c|c|c|}
\hline 8. BUS_SIZE & 1,827 & 2,948 & 0,774 & 5,367 & 0,32 & 0,24 & 0,53 & 0,65 & 0,19 & $-0,36$ & 0,21 & 1 & & & \\
\hline $\begin{array}{l}\text { 9. AREA_GEO } \\
\text { (Sud \& Islands) }\end{array}$ & 0,000 & 0,376 & 0,487 & 1,000 & $-0,25$ & $-0,42$ & $-0,33$ & $-0,61$ & $-0,26$ & 0,4 & $-0,17$ & $-0,64$ & 1 & & \\
\hline $\begin{array}{l}\text { 10. AREA_GEO } \\
\text { (Center) }\end{array}$ & 0,000 & 0,193 & 0,396 & 1,000 & $-0,01$ & 0,18 & $-0,05$ & $-0,01$ & 0,33 & 0,01 & $-0,08$ & $-0,05$ & $-0,37$ & 1 & \\
\hline $\begin{array}{l}\text { 12. AREA_GEO } \\
\text { (North-East) }\end{array}$ & 0,000 & 0,229 & 0,422 & 1,000 & 0,05 & 0,24 & 0,1 & 0,33 & $-0,06$ & $-0,29$ & 0,2 & 0,2 & $-0,41$ & $-0,28$ & 1 \\
\hline $\begin{array}{l}\text { 11. AREA_GEO } \\
\text { (North-West) }\end{array}$ & 0,000 & 0,202 & 0,403 & 1,000 & 0,26 & 0,06 & 0,33 & 0,38 & 0,04 & $-0,18$ & 0,08 & 0,59 & $-0,38$ & $-0,26$ & $-0,29$ \\
\hline
\end{tabular}

Note: Signif. level: 0 ‘***’ 0.001 '**’ 0.01 ‘*’ 0.05 ‘†' 0.1 ‘ ' 1

Table 1. Descriptive statistics and correlation matrix

Hierarchical multivariate regression models are implemented to assess the effect of Chinese community size, local specialisation in textile and clothing industry and Chinese entrepreneurial diversification on the share and growth of Chinese entrepreneurship in a 5-years window. The regression model was estimated using robust standard errors, which considers issues concerning heterogeneity and a lack of normality in the distribution of errors. Moreover, logarithmic transformation is applied to smooth the distribution dispersion of some variables such as CHIN_POP and POP_DEN. Finally, coefficients are standardised to allow us to better appreciate the actual significance of the variables and to compare their impacts on the dependent variable.

In Table 2 (Model 1, 2, and 3), we summarise the results for the share of Chinese entrepreneurship in 2009. All variables have a significant effect on the share of Chinese entrepreneurship. The effect of Chinese entrepreneurial diversification is negative. Therefore, our model confirms that the share of Chinese entrepreneurship is inclined to be higher where Chinese community is larger $(\mathrm{H} 1 \mathrm{a})$ and it's specifically driven by local and Chinese entrepreneurial specialisation (respectively $H 1 b$ and $H 1 c$ are either confirmed).

\begin{tabular}{|c|c|c|c|c|c|c|}
\hline & $\begin{array}{l}\text { Model } 1 \\
\text { Coeff. } \\
\text { (St.Err) }\end{array}$ & $\begin{array}{l}\text { Model } 2 \\
\text { Coeff. } \\
\text { (St.Err) }\end{array}$ & $\begin{array}{l}\text { Model } 3 \\
\text { Coeff. } \\
\text { (St.Err) }\end{array}$ & $\begin{array}{c}\text { Model } 4 \\
\text { Coeff. } \\
\text { (St.Err) }\end{array}$ & $\begin{array}{l}\text { Model } 5 \\
\text { Coeff. } \\
\text { (St.Err) }\end{array}$ & $\begin{array}{c}\text { Model } 6 \\
\text { Coeff. } \\
\text { (St.Err) }\end{array}$ \\
\hline \multicolumn{7}{|c|}{ Explanatory variables } \\
\hline CHIN_POP & $\begin{array}{l}0.797 \\
(0.085)^{* * *}\end{array}$ & $\begin{array}{l}0.600 \\
(0.083)^{* * *}\end{array}$ & $\begin{array}{l}0.652 \\
(0.084)^{* * *}\end{array}$ & $\begin{array}{l}-0.309 \\
(0.138)^{*}\end{array}$ & $\begin{array}{l}-0.251 \\
(0.143)^{*}\end{array}$ & $\begin{array}{l}-0.354 \\
(0.53)^{*}\end{array}$ \\
\hline LOC_SPEC & & $\begin{array}{l}0.647 \\
(0.083)^{* * *}\end{array}$ & $\begin{array}{l}0.698 \\
(0.118)^{* * *}\end{array}$ & & $\begin{array}{l}-0.189 \\
(0.219)\end{array}$ & $\begin{array}{l}-0.289 \\
(0.215)\end{array}$ \\
\hline CHIN_VAR & & & $\begin{array}{l}-0.203 \\
(0.079)^{*}\end{array}$ & & & $\begin{array}{l}0.401 \\
(0.144)^{* *}\end{array}$ \\
\hline
\end{tabular}

Control variables 


$\begin{array}{cllllll}\text { BUS_DEN } & -0.085 & -0.131 & -0.141 & 0.152 & 0.166 & 0.186 \\ \text { POP_DEN } & (0.075) & (0.067) \dagger & (0.065)^{*} & (0.121) & (0.123) & (0.119) \\ & 0.009 & 0.004 & 0.028 & 0.161 & 0.162 & 0.114 \\ \text { BUS_SIZE } & (0.086) & (0.076) & (0.074) & (0.139) & (0.139) & (0.135) \\ & (0.214 & -0.186 & -0.142 & 0.172 & 0.163 & 0.076 \\ \text { AREA-NW } & 0.077 & (0.082)^{*} & (0.081) \dagger & (0.149) & (0.149) & (0.147) \\ & (0.187) & (0.165) & (0.174) & (0.301)^{* * *} & (0.302)^{* * *} & (0.317)^{*} \\ \text { AREA-NE } & 0.290 & 0.250 & 0.397 & 0.746 & 0.785 & 0.467 \\ & (0.231) & (0.204) & (0.206) \dagger & (0.373)^{*} & (0.374)^{*} & (0.376) \\ \text { AREA-CEN } & 0.142 & -0.107 & -0.085 & 0.981 & 1.073 & 0.907 \\ & (0.170) & (0.114) & (0.159) & (0.274)^{* * *} & (0.294)^{* * *} & (0.290)^{* *} \\ (\text { Intercept) } & -0.186 & -0.039 & -0.129 & -0.592 & -0.634 & -0.458 \\ \text { N } & (0.123) & (0.111) & (0.113) & (0.197)^{* *} & (0.204)^{* *} & (0.207)^{*} \\ \text { R-squared } & 104 & 104 & 104 & 104 & 104 & 104 \\ \text { Adj. R-squared } & 0.647 & 0.792 & 0.7475 & 0.241 & 0.247 & 0.305 \\ \text { VIF max } & 0.621 & 0.707 & 0.7233 & 0.186 & 0.183 & 0.238 \\ \text { F-test } & 1.682 & 1.685 & 1.686 & 1.682 & 1.685 & 1.725 \\ \text { Note: Dep.var } & 25.11 & 32.06 & 30.92 & 4.36 & 3.89 & 4.58\end{array}$

Note: Dep.var is SHARE_CHIN in model 1, 2 and 3; and GROWTH_CHIN in model 4, 5 and 6.

Signif. level: 0 ‘***’ 0.001 '**’ 0.01 '*’ 0.05 ‘†’ 0.1 “ ' 1

Table 2. Hierarchical multivariate regression models.

Models 4, 5 and 6 refer to the growth of Chinese entrepreneurship. These models highlight three major issues. First, community size is negatively related to the growth of Chinese entrepreneurship (coefficient estimates negative and significant). This confirms $H 2 a$, which claims that the growth of Chinese entrepreneurship is smaller in provinces where the community is stronger. Second, local specialization does not affect the growth of Chinese entrepreneurship (model 5). Thus, H2b is not confirmed. Third, in the full model (6) the Chinese entrepreneurial diversification positively affects the growth rate. In other words, the growth was higher in the local systems characterised by a more heterogeneous distribution of Chinese businesses across industries. This confirms hypothesis $H 2 c$.

Finally, control variables suggest that growth does not depend on urbanisation level, business size and the business density. Further spatial effects are evident. Chinese entrepreneurship share decrease or increase slowly in the South provinces.

The hierarchical model is robust. The positive change in $\mathrm{R}^{2}$ obtained in the full models by including more variables as predictors confirms the goodness 
of the models. Furthermore, we compute the square root of Variance Inflation Factor (VIF), eventually weighted for the degrees of freedom, to test for collinearity among explanatory variables. These reported in Table 3. VIF values do not show serious multicollinearity. All values are significantly below the threshold value of 10 , which is generally considered as critical.

\section{Discussion}

In this study we investigate the drivers affecting the share and growth of Chinese entrepreneurship in Italian provinces. Specifically, we focus on three major drivers highlighted in literature: the size of the community, the specialisation in the fashion industry of the province, the industrial specialisation/diversification of Chinese entrepreneurship.

Our findings confirm the importance of community-ship in explaining the share of Chinese entrepreneurship On the one hand, the community supports Chinese entrepreneurs in getting access and share key resources for the start-up and development of their businesses, such as cheap and flexible labour, financial capital, and co-ethnic market (Wilson and Portes, 1980; Portes and Bach, 1985; Zhou, 2004; Zhou and Cho, 2010). On the other hand, entrepreneurship fuels community development mobilizing social capital and kinship networks, and attracting new members (Aldrich \& Waldinger, 1990; Portes \& Zhou, 1996; Clark \& Drinkwater, 1998; Zhou, 2004; Light \& Dana, 2013). Nevertheless, there is a limit to the spatial development of this virtuous cycle, as suggested by the negative relationship we found between community size and entrepreneurship growth rate. The manufacturing activities are no longer compatible with the specialisation and character of first settlement areas (as suggested by the statistical insignificance of LOC_SPEC). Thus, immigrants move into areas more compatible with the development of their business activities by extending their role within all stages of fashion value chain and attempting to exploit new market opportunities (as highlighted by positive effect of CHIN_VAR). The intra-group competition and the excessive pressure exercised by these entrepreneurial activities on local infrastructures and intangible assets (Clark and Drinkwater, 1998) lead Chinese to expand their spatial presence and technical specialisation. Gentrification and the increasing visibility of ethnic community increase the rate of conflict between natives and immigrants with the effect of pushing immigrants into other neighbourhood areas or in others close municipalities (Manzo, 2012; Ganzaroli and De Noni, 2017). However, new entrepreneurs do not leave the community tout court, but start-up their businesses in neighbour provinces where the entrepreneurial and social pressure is lower but may 
still benefit from being close to the community. Thus, ethnic enterprises are increasingly found outside spatially defined and culturally distinct enclaves, where the overlapping between community and entrepreneurship is thicker, but close enough to be still supported by the community. Therefore, ethnic enclave cannot be understood as urban phenomena, but needs to be interpreted at regional level. Figure 1 provides some initial support for such an argument. The growth of Chinese entrepreneurship is higher in the provinces surrounding Milan, in the north of Venice-Padua-Treviso area, around Turin, between Florence and Rome, around Naples. Thus, these entrepreneurs remain closely connected to the community, which continues to play an important role because of its institutional completeness and its capacity to support the start-up process of new businesses and integrate a regionally distributed value chain. The case of the Chinatown (Paolo Sarpi) in Milan provides a robust example of regional extension of Chinese enclave (Ganzaroli and De Noni, 2017). For instance, several Chinese entrepreneurs who moved to the province of Monza-Brianza specialising in fabric covering for furniture and sofas originally belong to Paolo Sarpi community.

Furthermore, this study confirms that the development of Chinese entrepreneurship is strongly tied to the specialisation of the province on fashion. Although the fundamental role played by textile and clothing industrial districts in facilitating the entry of Chinese entrepreneurship in a location have been already sustained (Lombardi et al., 2015), our analysis confirms that there is statistical significant relation between the specialisation of a province and the share of Chinese entrepreneurship in that province. As we suggested above, a mix of factors have contributed to make Italy one of the favourite destination of Chinese immigrants: the relatively lax immigration Italian policies, the family-based structure of Italian businesses and the difficulty of Italian firms (mainly within textile industrial districts) in finding local homeworkers and subcontractors; the Chinese (and specifically from Zhejiang province) inclination for entrepreneurship and for collaborative spirit of self-reliance and supporting (Chen, 2015); the specialisation of their origin region on textiles, clothing, leather and footwear (Wu, 2009) and the support network of fellow natives who have been already established in other European countries fostered the moving to Italian provinces (Chang, 2012). The crisis and the restructuring of the Italian textiles apparel industry and the opportunities for a low-skilled labour force (Ceccagno, 2003) made the initial perception of the Chinese immigrants within the fashion industrial districts as a resource. The settlement of Chinese in some regions drove the new incoming migrants fostering the development of the community in these areas. As a result, the 
increasing number of Chinese immigrants has slowly led to an empowerment process of Chinese community. The merge between matured experience within Italian value chain and community financial availability enhanced and speeded up the Chinese entrepreneurship process in the Italian fashion districts. Moreover, the low entry barriers, the compatibility between Chinese business approach and the demands of Italy's local, the family-based production environment and the preservation of the connection to origin country allow the Chinese to exploit their kinship and transnational networks, further influence the development of Chinese entrepreneurship (Dei Ottati, 2014). In addition, the growing Chinese entrepreneurship process provides employment for other Chinese immigrants, reinforces the relationship between Chinese entrepreneurship and community and fosters its extent.

In this context, the number of Chinese textile firms has continuously grown in the last decades. On the one hand, the Chinese entry into textile has reinvigorated an industry that was slowly declining, has increased the competitiveness of those local systems by lowering production and distribution costs, and has favoured the introduction of a new mode of organising production called pronto moda. On the other hand, the rising of a phenomenon named Made in Italy by Chinese (Lan and Zhu, 2014; Chen, 2015 ) is blamed of producing negative externalities for local Italian brands and producers. Moreover, Chinese firms are often blamed to use illegal means such as tax evasion, counterfeit products, irregular workers and illegal immigrant and underpaid employees.

Therefore, despite of the problems of social integration and illegal practices, the regression findings suggest that Chinese entrepreneurship plays a more and more critical role in sustaining the local development and growth of textile industrial districts. Conversely, the analysis shows that local textile specialisation does not affect the growth rate of Chinese microentrepreneurship. Moving away from the original settlements, Chinese tend to start up complementary or diversified businesses in neighbourhood provinces.

Finally, the effect of Chinese entrepreneurial diversification on the share and growth of Chinese entrepreneurship is expected to be different. On the one side, we predict a negative effect on the share due to historic large concentration in the fashion industry. On the other side, we expect the strong occurrence of Chinese businesses in the local textile industry and the large size of community produce at some point in time the need for startups in complementary services such as retailing, wholesaling, food and beverage or personal services. We believe that the need for related services 
makes the variety a better factor to support the growth of Chinese entrepreneurship compared to specialised entrepreneurship.

The increasing need for complementary services is limited compared to Chinese historical specialisation in textile and clothing industry. However, the positive effect of Chinese entrepreneurial diversification on the growth rate suggests the increasing importance of related and complementary activities. In despite of Chinese specialisation which is concentred in historic settlement, in the large cities where population density is higher, Chinese entrepreneurial diversification tends to rise in the peripheral provinces by confirming the regional development of Chinese enclave.

In this direction, the start-up of businesses offering complementary services to the community suggests the evolution and integration process of Chinese at regional level. Exploiting and supporting this growth is crucial for local sustainability and for multicultural development of territory.

Nowadays, the Chinese may be more than ever a resource for urban and suburban economic revitalisation. The case of Prato highlights the Chinese entrepreneurial attitude to entry into the growing market of pronto moda not occupied by local entrepreneurs (Dei Ottati, 2014) moving up from being subcontractors to being final producers. However, since Chinese are to be a very closed community and to internalise the benefits, it becomes crucial to identify the means to facilitate a rapid and effective integration process. Local policy makers need to support the integration process of Chinese businesses in the Italian fashion value chain, enhance the cultural assimilation of Chinese second-generations and improve the local relationships between Chinese and native entrepreneurs by identifying common strategic goals and development opportunities.

\section{Conclusion}

This study explores the drivers of share and growth of Chinese entrepreneurship in Italian provinces, following the immigrant entrepreneurship literature that has provided large evidences that immigrant entrepreneurship is an important driver for the economic growth of the host countries (Dana, 2007). Our finding suggests that the share of Chinese entrepreneurship positively relies on the size of the Chinese community, the textile specialisation of local systems where the community is established and the entrepreneurial capacity to be specialised too. Differently, we found that the growth of Chinese entrepreneurship is inclined to be higher in the neighbouring areas outside the community where the local specialisation on fashion industry is lower. This suggests that Chinese entrepreneurship is growing more outside urban areas where the competitive pressure and infrastructural constraints are lower, but close to the community enough to 
keep in touch and to benefit from its social and economic support. Furthermore, the development of Chinese entrepreneurship appears to be positively influenced by an increasing diversification process across industries. In this light, secondary data suggests that Chinese are diversifying their activities by integrating all stages of fashion value chain such as wholesale and retail, by exploiting new market opportunities or by filling supply gaps sometimes due to the exit of local firms because of economic crisis. This development trend pointing out a spatial and industrial extension of Chinese entrepreneurship strengths the Chinese institutional completeness, enhances the integration process and confirms the potential role played by ethnic entrepreneurship on local systems performances.

Despite interesting findings, several limitations need to be addressed. First, it refers to a single country and a single ethnic group. That is our findings are meaningful only for the development of Chinese entrepreneurship in Italy. Therefore, this study could be extended into two possible directions. On the one hand, developing a comparative analysis between countries to identify commonalities and differences in the development of Chinese entrepreneurship. This would allow a better understanding of push, pull and embedded factors in the development of Chinese entrepreneurship. On the other hand, developing a comparative analysis between ethnic groups. This would allow a better understanding of commonalities and differences in the development of entrepreneurship between ethnic groups. Second, our analysis is based on the comparison between provinces. This provides the analysis with greater robustness. However, as we already suggested, the development of Chinese entrepreneurship seems to give rise to completed regional systems/enclaves. Thus, it would be interesting to develop the same analysis at regional level. Third, we did not include in our analysis any variable related to China economy nor to other Chinese communities in the world. In the recent literature the significance of the transnational context in influencing the local development of immigrant entrepreneurship is highlighted. More specifically, in the case of Chinese entrepreneurship, long-distance connections between oversee communities seems to give rise to and facilitate coordination to ethnically globally distributed value chain. Thus, the significance of this latest aspect should be further explored.

\section{References}


Aldrich, H. E., \& Waldinger, R. (1990). Ethnicity and entrepreneurship. Annual review of sociology, 16, 111-135.

Asheim, B. T., Boschma, R., \& Cooke, P. (2011). Constructing regional advantage: Platform policies based on related variety and differentiated knowledge bases. Regional Studies, 45(7), 893-904.

Audretsch, D. B., Falck, O., Feldman, M. P., \& Heblich, S. (2012). Local entrepreneurship in context. Regional Studies, 46(3), 379-389.

Barbu, M., Dunford, M., \& Liu, W. (2013). Employment, entrepreneurship, and citizenship in globalised economy: the Chinese in Prato. Environment and Planning A, 45(10), 2420-2441.

Baycan-Levent, T., \& Nijkamp, P. (2009). Characteristics of migrant entrepreneurship in Europe. Entrepreneurship and regional development, 21(4), 375-397.

Ceccagno, A. (2003). New Chinese migrants in Italy. International Migration, 41(3), 187-213.

Ceccagno, A. (2009). Chinese migrants as apparel manufacturers in an era of perishable global fashion: new fashion scenarios in Prato, pp. 42-74 in Johanson, G., Smyth, R. and French, R. (eds), Living Outside the Walls: The Chinese in Prato, Newcastle upon Tyne, Cambridge Scholars Publishing

Chang, A. (2012). 20th century Chinese migration to Italy: The Chinese diaspora presence within European international migration. History Compass, 10(2), 179-190.

Chen, C. (2015). Made in Italy (by the Chinese): migration and the rebirth of textiles and apparel. Journal of Modern Italian Studies, 20(1), 111126.

Clark, K., \& Drinkwater, S. (1998). Ethnicity and self $\square$ employment in Britain. Oxford Bulletin of Economics and Statistics, 60(3), 383-407.

Dana, L. P. (2001). Networks, internationalisation \& policy. Small Business Economics, 16(2), 57-62

Dana, L. P. (Ed.). (2007). Handbook of research on ethnic minority entrepreneurship: A co-evolutionary view on resource management. Edward Elgar Publishing.

Dei Ottati, G. (2014). A transnational fast fashion industrial district: an analysis of the Chinese businesses in Prato. Cambridge Journal of Economics, 38(5), 1247-1274.

Dunford, M. (2006). Industrial districts, magic circles, and the restructuring of the Italian textiles and clothing chain. Economic Geography, 82(1), 27-59. 
Florida, R. (2005). The Flight of the Creative Class: The New Global Competition for Talent. Harper Collins Publishers Inc., New York.

Fondazione Leone Moressa (2015). Il valore dell'immigrazione. Franco Angeli.

Frenken, K., Van Oort, F., \& Verburg, T. (2007). Related variety, unrelated variety and regional economic growth. Regional studies, 41(5), 685-697.

Ganzaroli, A., \& De Noni, I. (2017). The rise of the Chinese regional cluster specializing in fashion in Lombardy: An evolutionary analysis. Journal of Enterprising Communities: People and Places in the Global Economy, 11(4), 491-513.

Ganzaroli, A., Orsi, L., \& De Noni, I. (2013). The evolution of the social understanding of ethnic entrepreneurship: results from a bibliometric analysis of the literature. International Journal of Entrepreneurship and Small Business, 20(4), 383-401.

Intesa Sanpaolo Servizio Studi e Ricerche. (2010). Economia e finanza dei distretti industriali, Report no. 3, December.

ISIC (2008), "International Standard Industrial Classification of All Economic Activities (ISIC), Rev 4, Statistics Revision”. New York: United Nations.

Klosterman, R. (1990). Microcomputers in urban and regional planning: lessons from the past, directions for the future. Computers, Environment and Urban Systems, 14(3), 177-185.

Klosterman, R., \& Rath, J. (2001). Immigrant entrepreneurs in advanced economies: mixed embeddedness further explored. Journal of ethnic and migration studies, 27(2), 189-201.

Laczko, F. (2003). Introduction: understanding migration between China and Europe. International Migration, 41(3), 5-19.

Lan, T., \& Zhu, S. (2014). Chinese apparel value chains in Europe: low-end fast fashion, regionalisation, and transnational entrepreneurship in Prato, Italy. Eurasian Geography and Economics, 55(2), 156-174.

Lee, S. Y., Florida, R., \& Acs, Z. (2004). Creativity and entrepreneurship: a regional analysis of new firm formation. Regional studies, 38(8), 879891.

Levent, T., Masurel, E., \& Nijkamp, P. (2003). Diversity in entrepreneurship: ethnic and female roles in urban economic life. International journal of social economics, 30(11), 1131-1161.

Light, I. and S. Gold (2000), Ethnic Economies, San Diego: Academic Press. 
Light, I., \& Dana, L. P. (2013). Boundaries of social capital in entrepreneurship. Entrepreneurship Theory and Practice, 37(3), 603624.

Liu, A. (1992). The 'Wenzhou model' of development and China's modernisation, Asian Survey, vol. 32, no. 8, 696-711

Lombardi, S., Lorenzini, F., Sforzi, F., \& Verrecchia, F. (2011, August). Chinese entrepreneurship in context: localisation, specialisation and their impact on Italian industrial districts. In 51st ERSA Congress, Barcelona (Vol. 30)

Lombardi, S., Lorenzini, F., Verrecchia, F., \& Sforzi, F. (2015). Chinese Micro-Entrepreneurship in Italy: A Place-Based Explanatory Analysis. In Baldassar, L., Johanson, G., McAuliffe, N., Bressan, M. (Eds.) Chinese Migration to Europe: Prato, Italy, and Beyond, Palgrave Macmillan, pp. 287-310.

Mameli F., Iammarino S., Boschma R. (2012). 'Regional variety and employment growth in Italian labour market areas: services versus manufacturing industries'. Papers in Evolutionary Economic Geography, 12.

Manzo, L. K. (2012). Emergent Spaces, Contemporary Urban Conflicts: Experiences of Social Mix in Changing Neighborhoods-The Case Study of Milan's Chinatown. In Living on the Boundaries: Urban Marginality in National and International Contexts (pp. 415-449). Emerald Group Publishing Limited.

Marsden, A., \& Caserta, D. (2010). Storie e progetti imprenditoriali dei cinesi di Prato. Camera di Commercio di Prato, Ufficio Studi, Prato, February.

Martin, R. (2012). Measuring knowledge bases in Swedish regions. European Planning Studies, 20(9), 1569-1582.

Masurel, E., Nijkamp, P., Tastan, M., \& Vindigni, G. (2002). Motivations and performance conditions for ethnic entrepreneurship. Growth and Change, 33(2), 238-260.

Ndofor, H. A., \& Priem, R. L. (2011). Immigrant entrepreneurs, the ethnic enclave strategy, and venture performance. Journal of Management, 37(3), 790-818.

Nijkamp, P. (2003). Entrepreneurship in a modern network economy. Regional Studies, 37(4), 395-405.

Ottaviano, G. I., \& Peri, G. (2005). Cities and cultures. Journal of Urban Economics, 58(2), 304-337. 
Ozgen, C., Nijkamp, P., \& Poot, J. (2013). The impact of cultural diversity on firm innovation: evidence from Dutch micro-data. IZA Journal of Migration, 2(1), 1-24.

Portes, A. 1981. Modes of structural incorporation and present theories of immigration. In M. Kritz, C. Keely, \& S. Tomasi (Eds.), Global trends in migration: 279-297. Staten Island, NY: CMS Press.

Portes, A., \& Bach, R. L. (1985). Latin journey: Cuban and Mexican immigrants in the United States. Univ of California Press.

Portes, A., \& Shafer, S. 2007. Revisiting the enclave hypothesis: Miami twenty-five years later. Research in the Sociology of Organisations, 25: 157-190.

Portes, A., \& Zhou, M. (1996). Self-employment and the earnings of immigrants. American Sociological Review, 61, 219-230.

Sanders, J. M., \& Nee, V. (1996). Immigrant self-employment: The family as social capital and the value of human capital. American sociological review, 231-249.

Santini, C., Rabino, S., \& Zanni, L. (2011). Chinese immigrants socioeconomic enclave in an Italian industrial district: the case of Prato. World Review of Entrepreneurship, Management and Sustainable Development, 7(1), 30-51.

Saxenian, A. (2002). Transnational communities and the evolution of global production networks: the cases of Taiwan, China and India. Industry and Innovation 9.3: 183-202.

Wilson, K. L., \& Portes, A. (1980). Immigrant enclaves: An analysis of the labor market experiences of Cubans in Miami. American journal of sociology, 86(2), 295-319.

Zhou, M. (2004). Revisiting ethnic entrepreneurship: convergences, controversies, and conceptual Advancements1. International migration review, 38(3), 1040-1074.

Zhou, M., \& Cho, M. (2010). Noneconomic effects of ethnic entrepreneurship: A focused look at the Chinese and Korean enclave economies in Los Angeles. Thunderbird International Business Review, 52(2), 83-96. 
